\title{
PENGARUH MODEL PEMBELAJARAN PROJECT BASED LEARNING BERBANTUAN MEDIA OUTDOOR TERHADAP KOMPETENSI PENGETAHUAN IPA KELAS V
}

\author{
Ni Luh Eri Kumala Dewi ${ }^{1}$, DB Ketut Ngurah Semara Putra ${ }^{2}$, I G A Agung Sri Asri ${ }^{3}$ \\ Jurusan Pendidikan Guru Sekolah Dasar \\ Universitas Pendidikan Ganesha \\ Singaraja, Indonesia \\ e-mail: erikumala@yahoo.co.id1. semara.putra@undiksha.ac.id2.igaagungsri.asri@undiksha.ac.id3
}

\begin{abstract}
ABSTRAK
Penelitian ini bertujuan untuk mengetahui perbedaan yang signifikan kompetensi pengetahuan IPA antara kelompok siswa yang dibelajarkan melalui model pembelajaran Project Based Learning berbantuan media Outdoor dengan kelompok siswa yang dibelajarkan melalui pembelajaran konvensional pada kelas V SD Gugus II Kuta Utara Tahun Ajaran 2017/2018. Rancangan penelitian Eksperimen semu dengan bentuk nonequivalent control group design. Populasi penelitian ini adalah seluruh siswa kelas V SD Gugus II Kuta Utara yang berjumlah 334 orang. Sampel dilakukan dengan teknik random sampling. Sampel dalam penelitian ini adalah kelas VA SD No. 1 Tibubeneng dengan jumlah 39 siswa sebagai kelompok eksperimen dan kelas VA SD No. 2 Tibubeneng dengan jumlah 33 siswa sebagai kelompok kontrol. Pengumpulan data dilakukan dengan menggunakan metode tes dalam bentuk tes objektif pilihan ganda biasa. Data yang diperoleh dianalisis menggunakan uji-t. Hasil analisis data diperoleh $t_{\text {hitung }}=3,890$ sedangkan pada taraf signifikansi $5 \%$ dan $\mathrm{dk}=70$ diperoleh nilai $t_{\text {tabel }}=2,000$ sehingga $t_{\text {hitung }}$ $=3,890>t_{\text {tabel }}=2,000$. Berdasarkan kriteria pengujian, maka $\mathrm{H}_{0}$ ditolak dan $\mathrm{H}_{\mathrm{a}}$ diterima. Adapun nilai rata-rata kompetensi pengetahuan IPA pada kelompok yang dibelajarkan melalui model pembelajaran Project Based Learning berbantuan media Outdoor adalah 82,18 , sedangkan pada kelompok yang dibelajarkan melalui pembelajaran konvensional adalah 75,76. Berdasarkan hasil tersebut dapat disimpulkan bahwa Model Pembelajaran Project Based Learning berbantuan media Outdoor berpengaruh terhadap kompetensi pengetahuan IPA kelas V SD Gugus II Kuta Utara Tahun Ajaran 2017/2018.
\end{abstract}

Kata Kunci: Project Based Learning, Outdoor, Kompetensi Pengetahuan IPA.

\begin{abstract}
This research's aims to know the significant difference of science competence between the group students with the Project Based Learning model assisted by outdoor media companed to group of students conventional method for fifth grade students of SD Gugus II in North Kuta academic year of $2017 / 2018$. This research is an experiment with the research design used is non-equivalent control group design. The populations of this research are all of the students of fifth grade which amount 334 students. The sample is determined by random sampling technique. The sample is students of fifth grade A in SD Number 1 Tibubeneng totaled 39 students as the experimental group and students of fifth grade A in SD Number 2 Tibubeneng totaled 33 students as the control group. Data collection technique using testing technique by objective test type multiple choice regular. Technique data abalysis using the $t$ test. The results showed that $\mathrm{t}_{\text {count }}=3,890$ and at significance level $5 \%$ and $\mathrm{dk}=70$ obtained $t_{\text {table }}=2,000$ sehingga $t_{\text {count }}=3,890>t_{\text {table }}=2,000$. Based on the criteria for testing, then $H_{0}$ is rejected and $\mathrm{H}_{\mathrm{a}}$ is accepted. The velue of science competence group with the Project Based Learning model assisted by outdoor media is 82,18 , and group of students with the conventional method is 75,76. Based on these result Project Based Learning model assisted by outdoor media environment affect the science competence fifth grade students of SD Gugus II North Kuta academic year of 2017/2018.
\end{abstract}

Keywords: Project Based Learning, Outdoor, Knowledge Science Competence. 


\section{Pendahuluan}

Pendidikan memegang peranan penting dalam mempersiapkan sumber daya manusia yang berkualitas. Upaya peningkatan mutu pendidikan di Indonesia saat ini merupakan kebutuhan yang tidak dapat ditunda-tunda lagi. Mengingat kualitas pendidikan kita sudah jauh tertinggal dari negara-negara tetangga, apalagi bila dibandingkan dengan negara-negara maju. Salah satu upaya yang dilakukan manusia untuk menghasilkan Sumber Daya Manusia (SDM) yang berkualitas yaitu dengan pendidikan. Oleh karena itu pendidikan hendaknya dikelola, baik secara kualitas maupun kuantitas. "Pendidikan adalah suatu proses dalam rangka mempengaruhi siswa supaya mampu menyesuaikan diri sebaik mungkin dengan lingkungannya, dan dengan demikian akan menimbulkan perubahan dalam dirinya yang memungkinkannya untuk berfungsi secara adekwat dalam kehidupan masyarakat" (Arsyad, 2013:3).Trianto (2014:1) menyatakan "pendidikan merupakan salah satu bentuk perwujudan kebudayaan manusia yang dinamis dan sarat perkembangan". Hal ini sependapat dengan Sukardjo dan Komarudin (2013:9) yang menyatakan "pendidikan kumpulan dari semua proses yang memungkinkan seseorang mampu mengembangkan seluruh kemampuan (potensi) yang dimilikinya". Berdasarkan hal tersebut, dapat disimpulkan bahwa pendidikan merupakan proses dalam hidup seseorang untuk mencapai perubahan dan mewujudkan potensi dari diri seseorang menjadi lebih baik.

Undang-Undang Sistem Pendidikan Nasional Nomor 20 Tahun 2003 terkait dengan sistem pendidikan nasional menyatakan pendidikan diselenggarakan sebagai suatu proses pembudayaan dan pemberdayaan peserta didik yang berlangsung sepanjang hayat, serta pendidikan diselenggarakan dengan memberi keteladanan dan mampu membangun kemauan, serta mengembangkan potensi dan kreativitas peserta didik. Paradigma pendidikan terjadi diberbagai bidang disiplin ilmu. Dalam Kurikulum 2013 salah satu muatan materi yang termuat yaitu IImu Pengetahuan Alam (IPA). Muatan IPA di SD menekankan pada pemberian pengalaman langsung dan siswa dituntut melakukan beberapa proses secara aktif mencari, mengolah, mengkonstruksi, dan menerapkan pengetahuan. Susanto (2013:167) menyatakan "IPA adalah usaha manusia dalam memahami alam semesta melalui pengamatan yang tepat pada sasaran, serta menggunakan prosedur dan dijelaskan dengan penalaran sehingga mendapatkan suatu kesimpulan". "IPA sebagai disiplin ilmu dan penerapannya dalam masyarakat membuat pendidikan IPA menjadi penting" (Samatowa, 2016:56).

Pembelajaran IPA yang menarik bukan hanya pengetahuan berupa fakta, konsep, dan teori, tetapi pembelajaran yang bermakna sehinga merangsang keingintahuan siswa terhadap pembelajaran dan lingkungannya. Dalam Kurikulum 2013 yang berlaku, terdapat aspek (ranah) yang dinyatakan di dalam rumusan kompetensi inti yaitu, (1) Kompetensi Inti-1 (KI-1) untuk kompetensi sikap spiritual, (2) Kompetensi Inti-2 (KI-2) untuk kompetensi sikap sosial, (3) Kompetensi

Inti-3 (KI-3) untuk kompetensi pengetahuan, (4) Kompetensi Inti-4 (KI-4) untuk kompetensi keterampilan. Aspek pengetahuan (KI-3) yang merupakan hasil belajar yang berkenaan dengan kemampuan berpikir, memperoleh pengetahuan, konseptualisasi, penentuan dan penalaran. Kosasih (2016) pembelajaran berbasis kompetensi merupakan serangkaian kemampuan peserta didik yang menyangkut aspek sikap, pengetahuan, keterampilan, yang didalamnya termasuk fisik dan mental peserta didik.

Jadi, dapat disimpulkan bahwa kompetensi pengetahuan merupakan gambaran suatu kemampuan siswa yang dapat diamati dan diukur seperti halnya dengan hasil belajar, dan kompetensi pengetahuan IPA merupakan perubahan tingkah laku siswa dari aspek kognitif setelah melalui latihan dan pengalaman yang dapat dipertanggung jawabkan dalam pemahaman mengenai pembelajaran IPA.

Kompetensi pengetahuan yang dicapai siswa ditentukan oleh berbagai faktor, diantaranya faktor kecerdasan, cita-cita siswa, motivasi, perhatian, lingkungan, sarana dan prasarana yang menunjang. Susanto (2013) menyatakan bahawa terdapat dua faktor yang dapat mempengaruhi kompetensi pengetahuan siswa yaitu faktor internal dan faktor eksternal. 
Dalam proses pembelajaran pada anak usia SD penerapan model-model pembelajaran membuat siswa aktif dan kreatif dalam mengikuti kegiatan pembelajaran. Berdasarkan observasi yang dilakukan dengan guru kelas V SD Gugus II Kuta Utara pada hari selasa, 16 Januari 2018, proses pembelajaran belum menerapkan model-model pembelajaran yang inovatif. Berkaitan dengan ini, maka sangat dibutuhkan untuk menerapkan inovasi dalam model-model pembelajaran di SD Gugus II Kuta Utara yang dilakukan secara intensif oleh guru pada pembelajaran IPA.

Oleh karena itu alangkah baiknya dalam pembelajaran diusahakan menggunakan pembelajaran yang menarik, menyenangkan dan berpusat pada siswa. Salah satu model pembelajaran tersebut adalah model pembelajaran Project Based Learning. Model pembelajaran Project Based Learning atau yang sering disebut juga model pembelajaran berbasis proyek. Dengan menggunakan model pembelajaran ini, siswa aktif dalam kegiatan pembelajaran dalam rangka memperoleh pengetahuan dan pengalaman belajar secara nyata. Widiasworo (2017) menyatakan siswa memiliki gaya belajar yang berbeda sehingga pembelajaran berbasis proyek memberikan kesempatan kepada siswa untuk menggali materi dengan menggunakan berbagai cara yang bermakna.

Karakteristik pembelajaran Project Based Learning antara lain a) Peserta didik membuat keputusan tentang sebuah kerangka kerja. b) Adanya permasalahan atau tantangan yang diajukan kepada siswa. c) Siswa mendesain proses untuk menentukan solusi atas permasalahan atau tantangan yang diajukan. d) Siswa secara kolaboratif bertanggung jawab untuk mengakses dan mengelola informasi untuk memecahkan permasalahan. e) Proses evaluasi dijalankan secara kontinu. f) Peserta didik secara berkala melakukan refleksi atas aktivitas yang sudah dijalankan. g) Produk akhir aktivitas belajar akan dievaluasi secara kualitatif. h) Situasi pembelajaran sangat toleran terhadap kesalahan dan perubahan. Sani (2014) menyatakan kelebihan model pembelajaran PjBL yaitu, meningkatkan motivasi siswa dalam belajar serta mendorong mereka untuk melakukan pekerjaan penting yaitu proyek percobaan, meningkatkan kemampuan siswa dalam bekerja sama dengan kelompok, membuat siswa lebih aktif dalam menyelesaikan permasalahan, mendorong siswa mempraktikkan keterampilan berkomunikasi bersama kelompok dengan baik, meningkatkan keterampilan siswa dalam mengelola sumber daya yang terdapat di lingkungan sekitarnya, memberikan pengalaman kepada siswa dalam mengorganisasi proyek, mengalokasikan waktu, dan mengelola sumber daya seperti peralatan dan bahan untuk menyelesaikan proyek, memberikan kesempatan belajar bagi siswa untuk berkembang sesuai kondisi dunia nyata yang terdapat dilingkungannya, melibatkan siswa untuk belajar mengumpulkan informasi dan menerapkan pengetahuan tersebut untuk menyelesaikan permasalahan di lingkungannya, membuat suasana belajar menjadi nyata dan menyenangkan.

Selain model pembelajaran yang menarik, untuk mengaktifkan siswa dan membuat pembelajaran menjadi menyenangkan yaitu dengan digunakannya media yang mampu menarik perhatian dan bermakna bagi siswa. Dengan digunakannya media Outdoor atau belajar yang dilakukan diluar kelas akan membuat siswa merasa lebih bebas bergerak dan memberikan pengalaman nyata pada siswa. Pengalaman nyata tersebut akan semakin konkret sehingga siswa akan terhindar dari kesalahan persepsi mengenai pembahasan materi pelajaran tertentu. Media Outdoor merupakan suatu kegiatan pembelajaran di luar kelas yang dapat menambah aspek kegembiraan dan kesenangan bagi siswa sebagaimana layaknya seorang anak yang sedang bermain di alam bebas (Widiasworo, 2017). Berdasarkan dari hal tersebut media outdoor dalam pembelajaran memberikan pengalaman yang berkesan, dan siswa dapat berpikir secara kritis dan objektif karena dalam pembelajaran tersebut siswa dapat memaksimalkan penggunaan indera yang mereka miliki demi mengembangkan rasa ingin tahu dan mencapai tujuan pembelajaran yang diinginkan.

Pembelajaran Project Based Learning berbantuan media Outdoor memberikan kesempatan kepada siswa untuk mengkonstruksi pengetahuan awal mereka dengan pengetahuan baru yang diperolehnya dengan cara memberikan pengalaman langsung dengan objek atau lingkungan belajarnya yaitu diluar kelas sebagai sumber/media belajarnya. Pembelajaran ini memberikan peluang pada sistem pembelajran yang berpusat pada siswa, 
lebih kolaboratif, dan siswa terlibat secara aktif menyelesaikan proyeknya secara mandiri dan bekerja sama dengan kelompok.

Pelaksanaan model pembelajaran Project Based Learning tentunya menggunakan langkah-langkah. Sebelum guru melaksanakaan langkah-langkah dari model pembelajaran Project Based Learning guru menyampaikan tujuan pembelajaran, kompetensi yang harus dicapai oleh siswa, dan gambaran singkat mengenai materi yang akan dipelajari. bahwa langkah-langkah model pembelajaran Project Based Learning diantaranya (1) Pengajuan pertanyaan (2) Mendesain perencanaan (3) Menyusun jadwal (4) Memonitoring (5) Menguji Hasil (6) Melakukan Evaluasi

Penelitian ini bertujuan untuk mendeskripsikan kompetensi pengetahuan IPA kelompok siswa yang dibelajarkan melalui model pembelajaran Project Based Learning berbantuan media Outdoor dengan kelompok siswa yang dibelajarkan melalui pembelajaran konvensional. Dan untuk mengetahui perbedaan yang signifikan kompetensi pengetahuan IPA antara kelompok siswa yang dibelajarkan melalui model pembelajaran Project Based Learning berbantuan media Outdoor dengan kelompok siswa yang dibelajarkan melalui pembelajaran konvensional pada kelas V SD Gugus II Kuta Utara Tahun Ajaran 2017/2018.

Berdasarkan paparan tersebut, dipandang perlu dilakukan penelitian terkait dengan upaya untuk mengetahui perbedaan kompetensi pengetahuan IPA siswa yang dibelajarkan melalui model pembelajaran project based learning berbantuan media outdoor dengan siswa yang dibelajarkan melalui pembelajaran konvensional. Penelitian ini mengambil objek penelitian pada siswa kelas V SD Gugus II Kuta Utara. Dari hal tersebutlah yang mendorong peneliti untuk mengadakan penelitian yang berjudul "Pengaruh Model Pembelajaran Project Based Learning Berbantuan Media Outdoor Terhadap Kompetensi Pengetahuan IPA Kelas V SD Gugus II Kuta Utara Tahun Ajaran 2017/2018".

\section{METODE}

Rancangan penelitian yang digunakan adalah quasi experimental design (desain eksperimen semu). Dalam desain eksperimen semu yang digunakan dalam penelitian ini adalah bentuk non-equivalent control group design. Dalam kaitannya dengan pemilihan subjek penelitian, peneliti tidak selalu dapat melakukan pemilihan subjek secara random. Desain penelitian eksperimen semu yang digunakan adalah desain Setyosari $(2015,211)$. Secara skematis desain penelitian ini digambarkan sebagai berikut.

\begin{tabular}{|llll|}
\hline O1 & $X$ & O2 & (eksperimen) \\
\hdashline O3 & & O4 & (kontrol) \\
\hline
\end{tabular}

\section{Gambar 1. Rancangan Kuasi Eksperimen}

Rancangan yang digunakan melibatkan dua kelompok kelas yaitu kelompok eksperimen dan kelompok kontrol. Kedua kelompok yang akan diteliti diberikan pretest dan posttest. (Sudijono, 2015:69) menyatakan "pretest adalah tes yang dilaksanakan sebelum bahan pelajaran diberikan kepada peserta didik". Berdasarkan hal tersebut, maka dalam penelitian ini Pretest digunakan sebagai penyetaraan kelompok untuk menentukan kelas sebagai kelompok eksperimen dan kelompok kontrol. Penelitian ini terdiri dari tiga tahapan yaitu, (1) tahan persiapan, (2) tahap pelaksanaan, (3) tahap eksperimen. Pada tahap persiapan langkahlangkah yang dilakukan yaitu, wawancara dengan kepala sekolah yang ada digugus II Kuta Utara, mempersiapkan silabus bersama wali kelas $\mathrm{V}$ yang terkait dengan materi yang diuji dalam penelitian, menyusun RPP (Rencana Pelaksanaan Pembelajaran), dengan model pembelajaran Project Based Learning berbantuan media Outdoor, mengkonsultasikan instrumen penelitian pretest dan posttest kepada wali kelas $\mathrm{V}$ dan dosen pembimbing, 
mengkonsultasikan RPP dan media pembelajaran kepada wali kelas dan dosen pembimbing, melakukan pengundian untuk menentukan Sampel dari seluruh populasi, memberikan pretest kepada 2 kelompok dari seluruh populasi yang telah diundi untuk membuktikan kesetaraan kelompok, untuk kesetaraan kelompok menganalisis data pretest kepada 2 kelompok populasi yang telah diundi dengan teknik uji t. Lalu melakukan pengundian kembali untuk menentukan kelompok eksperimen dan kelompok kontrol, dan mengadakan uji coba instrumen penelitian soal posttest. Pada tahap pelaksanaan penelitian kegiatan yang dilakukan adalah sebagai berikut, memberikan perlakuan pada kelas eksperimen berupa model pembelajaran project based learning berbantuan media outdoor, memberikan perlakuan pada kelas kontrol berupa pembelajaran konvensional, merlakuan diberikan sebanyak 6 kali di kelas eksperimen dan kontrol. Jumlah perlakuan yang diberikan terhadap kelas eksperimen dan kelas kontrol telah disesuaikan dengan jam pelajaran terkait materi dalam penelitian ini, dan memberikan posttest pada akhir eksperimen, kepada kelompok eksperimen dan kelompok kontrol. Pada tahap akhir penelitian yaitu sebagai berikut, menganalisis data dari hasil penelitian melakukan uji hipotesis.

Pada penelitian ini umumnya menggunakan sampel yang diambil dari suatu populasi yang ditentukan. Darmadi (2013:48) menyatakan "Populasi merupakan keseluruhan obyek atau subyek yang dijadikan sebagai sumber data dalam suatu penelitian dengan ciri-ciri seperti orang, benda, kejadian, waktu dan tempat dengan sifat atau ciri-ciri yang sama". Sugiyono (2016:117) menyatakan "Populasi bukan sekedar jumlah yang ada pada obyek atau subyek yang dipelajari tetapi, meliputi seluruh karakteristik atau sifat yang dimiliki oleh subyek atau obyek itu". Jadi, populasi adalah keseluruhan obyek atau subyek dalam penelitian yang memiliki ciri-ciri atau karakteristik yang sama. Populasi dari penelitian ini adalah seluruh siswa kelas V (lima) SD Negeri Gugus II Kuta Utara tahun Ajaran 2017/2018, yang terdiri dari 10 kelas dalam 7 sekolah dasar, diantaranya SD No. 1 Tibubeneng, SD No. 2 Tibubeneng, SD No. 3 Tibubeneng, SD No. 1 Canggu, SD No. 2 Canggu, SD No. 3 Canggu, dan SD No. 4 Canggu. Sampel penelitian merupakan suatu faktor penting yang perlu diperhatikan dalam penelitian yang dilakukan. Setyosari (2015:221) menyatakan "Sampel penelitian mencerminkan dan menentukan seberapa jauh sampel tersebut bermanfaat dalam membuat kesimpulan penelitian". Dan Darmadi (2013:50) menyatakan "Sampel adalah sebagian dari populasi yang dijadikan obyek atau subyek dalam penelitian". Jadi, sampel adalah sekelompok obyek, orang, peristiwa dan sebagainya yang merupakan representasi dari keseluruhan, sampel dalam penelitian dapat diartikan sebagai sejumlah kelompok kecil yang mewakili populasi untuk dijadikan sebagai objek penelitian

Teknik pengambilan sampel yang digunakan dalam penelitian ini adalah random sampling. "Random sampling adalah cara pengambilan sampel dengan memberikan kesempatan yang sama kepada anggota populasi untuk diambil menjadi anggota sampel" (Agung, 2014:71). Jadi, penggunaan random sampling karena pengambilan anggota dari populasi dilakukan secara acak tanpa memperhatikan strata yang ada dalam populasi, artinya pengambilan kelas dilakukan secara acak tanpa pilih-pilih.

Penggunaan random sampling karena pengambilan anggota dari populasi dilakukan secara acak tanpa memperhatikan strata yang ada dalam populasi, artinya pengambilan kelas dilakukan secara acak tanpa pilih-pilih. Pada pengambilan sampel, dari 10 kelas tersebut diundi untuk menentukan 2 kelas sebagai subjek penelitian yaitu satu kelas eksperimen dan satu kelas kontrol. Setelah dilakukan random maka kelas yang terpilih untuk menjadi kelas eksperimen adalah kelas $\mathrm{V}$ di SD No. 1 Tibubeneng yang dibelajarkan dengan model pembelajaran Project Based Learning berbantuan media Outdoor. Untuk kelas kontrol terpilih kelas di SD No. 2 Tibubeneng yang dibelajarkan dengan pembelajaran konvensional. Selanjutnya, dilakukan penyetaraan terhadap kedua sampel untuk memastikan tidak ada perbedaan rata-rata nilai kemampuan belajar IPA siswa. Dianalisis dengan menggunakan uji-t dengan rumus polled varians.

Fokus objek dalam penelitian ini adalah variabel. Agung (2014:39) menyatakan bahwa "variabel merupakan suatu konsep sangat penting di dalam penelitian". Dalam penelitian ini melibatkan dua variabel, yaitu variabel bebas dan variabel terikat. Adapun variabel dalam penelitian ini adalah 1) variabel bebas yaitu variabel yang menjadi penyebab terjadinya 
perubahan suatu fenomena yang diamati atau diteliti yaitu Model Pembelajaran Project Based Learning berbantuan Media Outdoor. Dan variabel terikat yaitu kompetensi pengetahuan IPA. Pada penelitian eksperimen perlu dilakukan pengendalian terhadap validitas penelitian. Validitas yang terkait dalam penelitian ini yaitu validitas internal dan validitas eksternal.

Data yang dikumpulkan dalam penelitian ini adalah data mengenai kompetensi pengetahuan IPA. Pengumpulan data yaitu menggunakan teknik tes. Tes merupakan metode untuk memperoleh data yang berbentuk suatu tugas yang harus dikerjakan oleh seseorang atau sekelompok orang yang dites (testee) dan dari tes ini dapat menghasilkan skor (Agung, 2014). Jenis tes yang digunakan yaitu tes objektif atau pilihan ganda biasa, yang setiap pertanyaan mempunyai beberapa jawaban yang salah, tetapi disediakan satu pilihan jawaban yang benar. Teknik tes ini digunakan untuk memperoleh data mengenai kompetensi pengetahuan IPA pada kelas eksperimen dengan menerapkan model pembelajaran Project Based Learning berbantuan Media Outdoor. Sebelum tes digunakan dilakukan validasi untuk menentukan layak tidaknya suatu instrumen yang terdiri dari uji validitas, uji reliabilitas, uji daya beda dan uji tingkat kesukaran. Dari uji validitas, uji reliabilitas, uji daya beda dan uji tingkat esukaran butir tes instrumen kompetensi pengetahuan IPA yang dapat digunakan hanya sebanyak 30 butir soal. Dari 31 soal yang sudah valid, reliabel sesuai dengan tingkat kesukaran, namun uji daya beda tes terdapat satu soal dengan klasifikasi jelek sehingga tidak dipergunakan dalam tes. Kemudian 30 butir soal tersebut yang diujikan kepada kelompok eksperimen dan kelompok kontrol pada tahap akhir eksperimen.

Teknik analisis data yang digunakan dalam penelitian ini adalah teknik analisis statistik deskriptif dan statistik inferensial melalui uji-t. "Statistik deskriptif adalah suatu cara pengolahan data yang dilakukan dengan jalan menerapkan rumus statistik deskriptif” (Agung, 2014:110). Teknik analisis statistik deskriptif dalam penelitian ini digunakan untuk mendeskripsikan data kompetensi pengetahuan IPA siswa yang dibelajarkan melalui model pembelajaran project based learning berbantuan media outdoor dan kompetensi pengetahuan IPA siswa yang dibelajarkan melalui pembelajaran konvensional saintifik. Statistik inferensial merupakan statistik yang digunakan untuk menganalisis data sampel dan hasilnya diberlakukan untuk populasi. Pada penelitian ini sebelum uji hipotesis yang dianalisis dengan uji-t terlebih dahulu mengukur uji prasyarat analisis yang terdiri dari uji normalitas dan uji homogenitas varians. Uji normalitas dilakukan untuk mengetahui apakah sebaran data berdistribusi normal atau tidak. Untuk menghitung uji normalitas dalam penelitian ini menggunakan chi square. Uji homogenitas varians dilakukan untuk mengetahui apakah sebaran data tersebut homogen atau tidak, yaitu dengan membandingkan kedua variansnya. Uji homogenitas dapat dilakukan apabila kedua kelompok data tersebut berdistribusi normal. Setelah data lulus uji prasyarat kemudian dilanjutkan dengan pengujian hipotesis dengan menggunakan analisis uji-t.

\section{HASIL DAN PEMBAHASAN}

Setelah diberikan perlakuan sebanyak 6 kali di akhir eksperimen baik di kelas eksperimen yang dibelajarkan dengan model pembelajaran Project Based Learning berbantuan media Outdoor maupun kelas kontrol yang dibelajarkan dengan pembelajaran konvensional diberikan posttest untuk memperoleh data kompetensi pengetahuan IPA siswa.

Berdasarkan analisis deskriptif data kompetensi pengetahuan IPA Siswa Kelas V kelompok eksperimen dengan nilai tertinggi yang diperoleh 96 dan nilai terendah adalah 66 . Dari sebaran data tersebut diperoleh rata-rata (mean) sebesar 82,18, standar deviasi kompetensi pengetahuan IPA pada kelas eksperimen adalah 6,73 dan variansnya 45,36. Berdasarkan hasil perhitungan tersebut, dengan membandingkan rata-rata presentase yang diperoleh yaitu $82,18=82$, kemudian dengan kriteria PAP Skala Lima angka rata-rata 82,18 berada pada kategori 80-89. Maka dapat disimpulkan bahwa kriteria rata-rata tersebut tergolong tinggi. Sedangkan nilai rata-rata kompetensi pengetahuan IPA Siswa Kelas V kelompok kontrol dengan nilai tertinggi yang diperoleh 86 dan nilai terendah adalah 60 . Dari sebaran data tersebut diperoleh rata-rata (mean) sebesar 75,76, standar deviasi kompetensi pengetahuan IPA pada kelas kontrol adalah 7,24 dan variansnya 52,38. Berdasarkan hasil 
perhitungan tersebut, dengan membandingkan rata-rata presentase yang diperoleh yaitu 75,76 $=82$, kemudian dengan kriteria PAP Skala Lima angka rata-rata 75,76 berada pada kategori 65-79. Maka dapat disimpulkan bahwa kriteria rata-rata tersebut tergolong sedang.

Data nilai kompetensi pengetahuan IPA menunjukkan bahwa kelompok yang dibelajarkan melalui model pembelajaran Project Based Learning berbantuan media Outdoor memiliki ratarata yang lebih tinggi dari kelompok yang dibelajarkan melalui pembelajaran konvensional. Sebelum dilakukan uji hipotesis, terlebih dahulu dilakukan uji normalitas dan uji homogenitas varians.

Hasil uji normalitas sebaran data kompetensi pengetahuan IPA pada kelompok eksperimen diperoleh $\mathrm{X}^{2}$ hitung $=5,11$ sedangkan untuk taraf signifikansi $5 \%(\alpha=0,05)$ dan derajat kebebasan $(\mathrm{dk})=5$ diperoleh $\mathrm{X}_{\text {tabel }}^{2}=11,07$, karena $\mathrm{X}^{2}$ hitung $=5,11<\mathrm{X}_{\text {tabel }}^{2}=11,07$ maka $\mathrm{H}_{0}$ diterima. Ini berarti sebaran data kompetensi pengetahuan IPA pada kelompok eksperimen berdistribusi normal. Sedangkan pada kelompok kontrol diperoleh $X^{2}{ }_{\text {hitung }}=5,23$ sedangkan untuk taraf signifikansi $5 \%(\alpha=0,05)$ dan derajat kebebasan $(\mathrm{dk})=5$ diperoleh $\mathrm{X}^{2}$ tabel $=11,07$, karena $X^{2}$ hitung $=5,23<X_{\text {tabel }}^{2}=11,07$ maka $\mathrm{H}_{0}$ diterima. Ini berarti sebaran data kompetensi pengetahuan IPA pada kelompok kontrol berdistribusi normal.

Pada uji homogenitas diperoleh $\mathrm{F}_{\text {hitung }}=0,86$, harga ini kemudian dibandingkan dengan harga $F_{\text {tabel }}$ dengan derajat kebebasan pembilang $=33-1=32$ dan derajat kebebasan penyebut $=39-1=38$ dengan taraf signifikasi $5 \%$, sehingga diperoleh $F_{\text {tabel }}=1,76$. Karena harga $F_{\text {hitung }}<F_{\text {tabel }}(0,86<1,76)$. Ini berarti varians data kompetensi pengetahuan IPA kedua kelompok adalah sama atau homogen.

Berdasarkan hasil uji prasyarat analisis data, diperoleh kedua kelompok yaitu kelompok eksperimen dan kelompok kontrol berdistribusi normal dan homogen. Setelah data lulus uji prasyarat data tersebut maka dilanjutkan dengan uji hipotesis penelitian. Uji hipotesis yang digunakan dalam penelitian ini adalah uji beda mean (uji-t) dengan rumus polled varian karena varian kedua kelompok homogen.

Berdasarkan analisis data diketahui bahwa $t_{\text {hitung }}=3,890$, dan $\mathrm{dk}=70$ dengan taraf signifikansi adalah $5 \%$ diperoleh $t_{\text {tabel }}=2,000$. Hal ini berarti nilai $t_{\text {hitung }}>t_{\text {tabel }}$ yaitu $3,890>$ 2,000 sehingga $\mathrm{H}_{0}$ ditolak. Adapun hasil analisis uji-t dapat dilihat pada tabel 01 .

Tabel 01. Hasil Analisis Hipotesis

\begin{tabular}{lcccccc}
\hline Kelompok Sampel & $\mathrm{N}$ & $\mathrm{Dk}$ & $\mathrm{M}$ & $\mathrm{t}_{\text {hitung }}$ & $\mathrm{t}_{\text {tabel }}$ & Keterangan \\
\hline Eksperimen & 39 & 70 & 82,18 & 3,890 & 2,000 & $\begin{array}{c}\mathrm{H}_{0} \\
\text { Kontrol }\end{array}$ \\
\hline
\end{tabular}

Dengan demikian dapat disimpulkan bahwa terdapat perbedaan yang signifikan kompetensi pengetahuan IPA antara kelompok siswa yang dibelajarkan melalui model pembelajaran Project Based Learning berbantuan media Outdoor dengan kelompok siswa yang dibelajarkan melalui pembelajaran konvensional kelas V SD Gugus II Kuta Utara Tahun Ajaran 2017/2018. Sesuai dengan hasil penelitian yaitu adanya perbedaan yang siginifikan menunjukkan bahwa model pembelajaran Project Based Learning berbantuan media Outdoor berpengaruh terhadap kompetensi pengetahuan IPA.

Berdasarkan hasil temuan pada kedua kelompok dapat diketahui bahwa kedua kelompok awalnya memiliki kemampuan setara, lalu setelah diberikan perlakuan yang berbeda antara kelompok eksperimen dan kelompok kontrol maka perolehan nilai kompetensi pengetahuan IPA memiliki perbedaan. Kompetensi pengetahuan IPA kelompok eksperimen lebih baik dibandingkan dengan kompetensi pengetahuan IPA kelompok kontrol. Hal tersebut dapat dilihat dari rata-rata kelompok eksperimen dan kelompok kontrol. Perbedaan kompetensi pengetahuan yang telah dinormalisasi, rata-rata kelompok eksperimen lebih tinggi dibandingkan dengan kelompok kontrol, hal tersebut disebabkan oleh perlakuan berupa model pembelajaran 
Project Based Learning berbantuan media Outdoor yang diberikan kepada kelompok eksperimen. Model pembelajaran Project Based Learning berbantuan media Outdoor terlaksana dengan baik dan optimal. Pembelajaran Project Based Learning berbantuan media Outdoor memberikan kesempatan kepada siswa untuk mengkonstruksi pengetahuan awal mereka dengan pengetahuan baru yang diperolehnya dengan cara memberikan pengalaman langsung dengan objek atau lingkungan belajarnya yaitu diluar kelas sebagai sumber atau media belajarnya. Pembelajaran ini memberikan peluang pada sistem pembelajran yang berpusat pada siswa, lebih kolaboratif, dan siswa terlibat secara aktif menyelesaikan proyeknya secara mandiri dan bekerja sama dengan kelompok.

Hasil penelitian ini memperkuat simpulan penelitian yang dilakukan oleh Kamayani (2013) dengan Judul "Pengaruh Model Pembelajaran Project Based Lerning Berbantuan Media Tiga Dimensi Terhadap Hasil Belajar IPA Di SD Gugus IX Kecamatan Buleleng". Dan penelitian kedua yang dilakukan oleh Aprianti (2017) dengan judul "Pengaruh Model Project Based Learning berbasis Outdoor Study Terhadap Hasil Belajar IPA Siswa Kelas V SD Gugus II Mengwi Badung Tahun Ajaran 2016/2017. Berdasarkan paparan tersebut dapat disimpulkan bahwa model pembelajaran Project Based Learning berbantuan media Outdoor berpengaruh terhadap kompetensi pengetahuan IPA kelas V SD Gugus II Kuta Utara Tahun Ajaran 2017/2018.

\section{SIMPULAN DAN SARAN}

Berdasarkan hasil analisis nilai kompetensi pengetahuan IPA menunjukkan bahwa nilai rerata siswa yang mengikuti pembelajaran menggunakan model pembelajaran Project Based Learning berbantuan media Outdoor $(X=82,18$ ) yang berada pada kategori tinggi dan siswa yang dibelajarkan melalui pembelajaran konvensional ( $X=75,76$ ) yang berada pada kategori sedang.

Dari hasil perhitungan analisis data dengan menggunakan uji-t diperoleh $t_{\text {hitung }}=3,890$ dan dengan taraf signifikan $5 \% \mathrm{dk}=70$ diperoleh $t_{\text {tabel }}=2,000$ maka 3,890 $>2,000$ ini berarti bahwa terdapat perbedaan yang signifikan kompetensi pengetahuan IPA antara kelompok siswa yang dibelajarkan melalui Model pembelajaran Project Based Learning berbantuan media Outdoor dengan kelompok siswa yang dibelajarkan melalui pembelajaran Konvensional pada kelas V SD Gugus II Kuta Utara Tahun Ajaran 2017/2018. Dengan perbandingan hasil perhitngan rata-rata kompetensi pengetahuan IPA kelompok eksperimen yang dibelajarkan dengan model pembelajaran Project Based Learning berbantuan media Outdoor lebih tinggi dibandingkan dengan kelompok kontrol yang dibelajarkan dengan pembelajaran konvensional.

Ini berarti adanya perbedaan yang signifikan kompetensi pengetahuan IPA kelompok siswa yang dibelajarkan melalui model pembelajaran Project Based Learning Berbantuan Media Outdoor dengan kelompok siswa yang dibelajarkan melalui pembelajaran konvensional pada kelas V SD Gugus II Kuta Utara Tahun Ajaran 2017/2018. Atau model pembelajaran Project Based Learning berbantuan media Outdoor berpengaruh terhadap kompetensi pengetahuan IPA kelas V SD Gugus II Kuta Utara Tahun Ajaran 2017/2018.

Berdasarkan hasil penelitian, pembahasan dan kesimpulan maka dapat diajukan beberapa saran sebagai berikut: 1) Kepada guru disarankan lebih kreatif dan terampil untuk memberikan variasi strategi dan model dalam kegiatan pembelajaran. fasilitas berupa media belajar bagi siswa pada pembelajaran IPA dengan menggunakan model pembelajaran Project Based Learning berbantuan media Outdoor sehingga tercipta pembelajaran bermakna dan menyenangkan bagi siswa, 2) Kepada kepala sekolah agar penggunaan model pembelajaran Project Based Learning berbantuan media Outdoor ini dapat menjadi salah satu upaya untuk mengembangkan sekolah ke arah yang lebih baik terutama kualitas pembelajaran, 3) kepada peneliti lain disarankan supaya hasil penelitian ini digunakan sebagai referensi untuk melaksanakan penelitian selanjutnya. 


\section{DAFTAR RUJUKAN}

Agung, A. A. G. 2014. Metodologi Penelitian Pendidikan. Yogyakarta: Aditya Media Publishing.

Agung, A. A. G. 2016. Statistika Dasar untuk Pendidikan. Yogyakarta: Deepublish

Aprianti, Ni Putu Chyntia Dewi. 2017. Pengaruh Model Project Based Learning Berbasis Outdoor Study Terhadap Hasil Belajar IPA Siswa Kelas V SD Gugus II Mengwi Badung Tahun Ajaran 2016/2017. Skripsi.Jurusan Pendidikan Guru Sekolah Dasar. Singaraja: Universitas Pendidikan Ganesha.

Arsyad, Azhar. 2013. Media Pembelajaran. Jakarta: PT Rajagrafindo Persada.

Darmadi. 2013. Metode Penelitian Pendidikan dan Sosial. Bandung: Alfabeta .

Departemen Pendidikan dan Kebudayaan. 2014. Peraturan Menteri Pendidikan dan Kebudayaan Republik Indonesia Nomor 103A Tahun 2014 Salinan Lampiran tentang Pembelajaran Pada Pendidikan Dasar dan Pendidikan Menengah. Jakarta: Departemen Pendidikan dan Kebudayaan.

Kamayani, I. A Diah. 2013. "Pengaruh Model Pembelajaran Project Based Learning Berbantuan Media Tiga Dimensi Terhadap Hasil Belajar IPA di SD Gugus IX Kecamatan Buleleng". Mimbar PGSD Undiksha., Volume 1, Nomor 1 (hlm 1-10) (diakses tanggal 11 Januari 2018).

Kemendikbud. 2003. Undang-undang Republik Indonesia No. 20 Tahun 2003 tentang Sistem Pendidikan Nasional. Jakarta: Departemen Agama.

Kosasih. 2016. Strategi Belajar dan Pembelajaran Implementasi Kurikulum 2013. Bandung: Yrama Widya

Samatowa, Usman. 2016. Pembelajaran IPA di Sekolah Dasar. Jakarta: PT Indeks

Sani, Ridwan Abdullah. 2014. Pembelajaran Saintifik untuk Implementasi Kurikulum 2013. Jakarta: PT Bumi Aksara.

Setyosari, Punaji. 2015. Metode Penelitian Pendidikan dan Pengembangan. Jakarta: PT Kharisma Putra Utama

Sudijono, Anas. 2015. Pengantar Evaluasi Pendidikan. Jakarta: Rajawali Pers.

Sukardjo, M dan Komarudin Ukim. 2013. Landasan Pendidikan. Cetakan ke-5. Jakarta: PT Raja Grafindo Persada.

Susanto, Ahmad. 2013. Teori Belajar dan Pembelajaran di Sekolah Dasar. Jakarta: Kencana Prenada Media Grup.

Trianto. 2014. Mendesain Model Pembelajaran Inovatif, Progresif, dan Kontekstual. Jakarta: Prenadamedia Grup.

Widiasworo, Erwin. 2017. Strategi dan Metode Mengajar Siswa di Luar Kelas. Yogyakarta: Ar Ruzz Media. 